\title{
Islamophobia in Karine Tuil's The Age Of Reinvention Novel
}

\author{
Ellita Permata Widjayanti \\ Universitas Negeri Jakarta \\ E-mail: ellita.permata@gmail.com
}

\begin{abstract}
Islamophobia constitutes a negative action, attitude, and prejudice towards Islam as an ideology and against Muslims as followers of the ideology. It exists in any context and media including fictional works. This article discusses Islamophobia in an (English-translated) French novel entitled The Age of Reinvention written by Karine Tuil. The discussion focuses on how Islam and Muslims are represented in the novel and how the author uses some ironies to convey certain ideology. The author tends to be Islamophobic by describing Muslims as fatalist and immoral, and Islam as an uncivilized religion, barbaric, supportive of terrorism and irrational. Through the characters, narrations, and dialogues, the author also tends to have sentiment on some issues related to Islam.
\end{abstract}

Keywords: Islamophobia, Islam, Muslims, ideology, irony, sentiment

\section{INTRODUCTION}

The term Islamophobia has emerged in the 1980s, but the term is more popularly used after World Trade Center attacks on 9 September 2001 in America. The term has become established in academia dedicated to it. However, in many European countries, there is still a great amount of opposition to the term (Bayrakli, 2015: 6).

Islamophobia, according to Ramberg (2004: 6) can be defined as the fear of or prejudiced viewpoint towards Islam, Muslims and matters pertaining to them. The term Islamophobia is sometimes used as a synonym for "Arabophobia" which means a strong hatred and fear of the Arabs (Manqoush, 2014: 74). Criticism of Muslims or of the Islamic religion is not necessarily Islamophobic. Islamophobia operates by constructing a static 'Muslim' identity, which is attributed in negative terms and generalized for all Muslims (Bayrakli, 2015: 7). Islamophobia, is not a racist issue, but more ideological (Sayid, 2014: 17). Races were never exclusively biologically determined but rather socially and politically produced. Bodies were marked at the same time as religion and culture, history and territories (Sayid, 2011: 4). Muslims are homogenized and degraded by Islamophobic discourse and practices in their everyday lives (Garner, 2014: 9).

Iqbal (2010: 584) studied Islamophobia at three heuristic steps ranging from mild to strong. At the mild level, it includes avoidance from Muslims/Islam. At middle level, it includes negative emotions/feeling and ridiculous attitude towards Muslims/Islam. At strong level hatred, it includes rejection, insult and racial contempt attributes.

Grosfoguel (2012: 11-30) states some more conceptual forms of Islamophobia. First, Islamophobia as a form of cultural racism, namely the inferior attitude towards a group of people in terms of habits, beliefs, attitudes, and values. 
Contemporary notions commonly attached to other religions are 'uncivilized, barbaric, barbarous, primitive, backward, authoritarian and terrorist. Second, Islamophobia as orientalism. One of the racist arguments against today's Muslims is the patriarchal and sexist issue of women. As part of the construction of Muslim inferiority in relation to the west, the argument maintained is how Muslims are regarded as 'uncivilized and 'breaking' rules in the issue of women's pressures in the hands of men.

Third, Islamophobia as epistemic racism is an inferior attitude toward non-Western thinking that can lead to Orientalism. Muslim thinkers are considered inferior to Western/ Christian thinkers. Fourth, Islamophobia as eurocentric social science; Islam is regarded as an irrational doctrinal religion. This doctrine is considered to make Muslims an irrational fatalist. Islam is considered incommensurable with the superiority of Western values due to lack of individuality, rationality, and science.

Thus, Islamophobia is a negative action, attitude, and prejudice towards Islam as an ideology and against Muslims as followers of the ideology. It regards Islam and Muslims as 'others' who cannot engage with the social community of the world; Islam is negated and needs to be removed.

The discourse and image of Islam in Islamophobic media give a negative and unbalanced frame of Muslim image. Muslims are cornered, portrayed as evil, spreaders of terror and marginalized as 'other'. Kunst (2012) did a survey which showed that almost all participants had experience negative portrayals of Muslims in the media.

One of the mainstream media in the United States, Wall Street Journal, for example, has used the power of discourse in exacerbating the image of Islam and Muslims. In any constellation of global power, Islam is positioned as the enemy of western, capitalism, secularism, modernity, Christianity, Judaism, even as an enemy of women and individualism (Huntingon and Lewis in Joseph and D'harlingue, 2012: 159). Only a few of media portrays Muslims positively. Guardian, as has been examined by Kabgani (2013), although it is a nonIslamic media, gives positive portrayal on Muslim women, who are presented as active figures in Muslim community.

Islamophobia in various media is raised through the irony that is contradictory to the real concept, paradigm, and situation, as Islam is not interpreted deeply and holistically. The word 'irony' comes from the Greek eironeia, which means ignorance, pretending, hiding something (Colebrook, 2004:1-2). According to Colebrook (2014: 15) irony is to say something contrary to what is understood. This definition becomes clear because irony is a form of satire that has a double meaning, but it is more precisely embedded in the definition of verbal irony.

Kreuz and Roberts (in Attardo, 2007: 136) distinguish irony into four types. First, Socratic irony that is a condition in which a person pretends not to know about a particular topic for pedagogical purposes. Second, dramatic irony as a situation where the audience knows things unknown to the characters in a play. It is an incongruity between a situation developed in a drama and the accompanying words or actions that are understood by the audience but not by the characters in the play (Merriam Webster dictionary).

Third, irony can also be situational. Murfin and Supriyia Ray (in Manquosh et al. 2014: 75) argue that situational irony comes from events or situations themselves, as opposed to the statements made by a person, whether he understands the situation of irony or not. This irony usually involves a gap between hope and reality. Fourth, verbal irony, which is defined in Merriam Webster's dictionary as the use of words expressing something different from its literal meaning. This irony is often used to criticize a person or situation during an event, which turns out to be different from the expectations.

Islamophobic thought through those ironies is examined by Manqoush, et al (2014). They found that Lorraine Adams in his Harbor and John Updike through Terrorist made fun of Muslims. Through the characters in their works, they pouted the 'fanatical attitude' that sees women in hijab as good Muslims. They ridiculed the voice associated with the problems between the Middle East and America and also illustrate that Muslims have only one dimensional point of view.

The Islamophobic novelist creates spaces of 
negative perception of Islam and Muslims through characterization, narration, plot, diction and other intrinsic elements. One of the latest works in Europe that became an international bestseller, became a finalist of the Prix Goncourt and indicated as Islamophobic is an (English-translated) French novel entitled The Age of Reinvention (TAoR) written by Karine Tuil. This article will then discuss how Islam and Muslims are represented in the novel by analyzing the narrations and dialogues, which propose a particular discourse that leads to Islamophobia. The excerpts of selected narrations and dialogues are collected and then analyzed into some parts of discussions based on the apparent issues. Grosfoguel's theories of Islamophobia and the concept of ironies by Colebrook and Kreuz are used as a theoretical framework to reveal the author's Islamophobic ideology. The other concepts of Islamophobia mentioned above are also used to strengthen the arguments that the author used the narrations to convey certain ideology to be 'injected' to the readers through her views on Islam and Muslims.

\section{NEGATIVE CHARACTERIZATION ON MUSLIM CHARACTERS}

Karine Tuil uses the characters in her novel as a vessel to convey or even to inject certain ideas, which in this case is her view of Islam and Muslims. There are three Muslim characters in TAoR namely Samir Tahar, François Yahyaoui and Nawel Yahyaoui. The three characters, through narrator's narration, character's reaction, and dialogues are described as having negative traits.

Samir Tahar, as the main character, is described as an Arab and Muslim who is a maniac of sex. He has sex with many women even though he has already got married. It is described by the narrator in the following narration:

"You saw him and you thought: Yes, that mainly authority, that animal magnetismfuel for sex. Everything about him promised pleasure; everything about him betrayed his desire-an aggressive, corrupting desire. That was the most disturbing thing about him, this guy they knew nothing about: his sincerity in conquest. It was the first thing you noticed: his taste for women-for sex, his weakness even then-perceptible in his ability to seduce them instantly, almost automatically, his sexual voracity, which he didn't even try to control, which he was able to express in a single gaze (a fixed, piercing, pornographic gaze that unveiled his thoughts and was constantly on the lookout for the slightest hint of reciprocation).." (p.8).

He is such a maniac that he even has sex with many women, including his colleagues. He also has a mistress to meet his sexual needs.

Samir Tahar is also described as a liar master by transforming his identity into a Jew. He changes his name 'Samir', which sounds like more Arabian and Muslim, into 'Samuel' which sounds like a Jewish name. He claims to be a Jew and married a Jewish woman. He becomes rich and popular on his fake identity. He lives on lies on lies.

No better than Samir Tahar, Nawel Yahyaoui, Samir Tahar's mother, is also described as a bad Muslim. Although it is not clearly described whether she is a devout Muslim or not, she is portrayed as a Muslim woman who is no different from European women in general who get along freely; free to decide to have sex with any man. In fact, in Islam, women must maintain their honor and dignity. They must not have sex with any man except their husband in a legal marriage. However, in the plot of this novel, there is one occasion when Nawel Yahyaoui is asked to serve her boss' lust. She serves his boss, François Brunett, happily despite the fact that he is not her husband. In the following narration, it is clearly depicted how much Nawel enjoys her intimate relationship with Brunett when he asked her to make love.

He tells her to relax and she lies still. He tells her do this to me, do that to me, and she does. But the situation is more ambiguous than it appears. She does these things because she wants to. With him, she feels free. For the first time in her life, she surrenders to the desire of a man who really looks at her. She loves it. She submits." (P.76-77).

This depiction strengthens the character of Nawel as a Muslim woman who cannot maintain her dignity and honor. She simply gives herself 
unconditionally to a man who is not her husband, and she does so with pleasure. This character does not correspond to the real Islam tenets about women. This situation becomes situational irony since Nawel, who has passed many difficult situations in her life, is expected to be good Muslim (as she always expects to Samir Tahar). She breaks it by having a scandal with her boss; a banned shameful action in Islamic tenet. Orientalists see women as the creatures of a male power-fantasy. They express unlimited sensuality, they are more or less stupid, and above all they are willing (Said, 1977: 207).

Another major Muslim character is François Yahyaoui. He is the half brother of Samir Tahar. He was born out of the banned relationship of Nawel Yahyaoui with his boss, François Brunett. Previously he is described as a person who does not belong to Islam or any religion, but then in the middle of the plot, he learns about Islam, 'converts' to it and changes his name into François-Djamal. Before embracing Islam, through Nawel character, François is depicted as someone with a difficult and fragile personality. Nawel explains this thing to Samir Tahar as follows:

The problem is him. His difficult personality, the people he hangs around with, his fragile nature, his wanderings. "He does nothing all day. He's not like you: whatever he tries to do, he fails. He gave up school at fourteen. He's never managed to stay in job for longer than a week. He was offered a job at a market stall, but he couldn't get up in the mornings. He just hangs around, basically. He says he can't find anything. It's like he's doing it deliberately." (p. 158-159).

François is also a sex maniac with ownership of dozens of pornographic DVDs that he even does not try to hide from his mother. He also loves listening to the songs that have sexual nuances (p. 165). This is also reinforced by the incident when he is drunk in New York and encounters sexy women. He tries to seduce and rape the woman (p.218).

His brutal treatment of women does not change when he has studied Islam and married a Muslim woman named Nora. When they are fighting and Nora asks for a divorce, François sexually assaults her. The narrator describes it with a phrase "...rapes her brutally" (p. 300).

The narrator compares François to Samir Tahar by the narration: "Intellectually, socially, they are in absolute opposition. François gave up school after failing his professional exam in mechanics; he writes and speaks poorly-a savage, thinks Samir." (p.163). François then is someone who is poorly educated and exposed to a very bad environment. He always uses bad and dirty words when talking to others, including to his brother and mother.

The folly of François is 'exploited' by Tuil by presenting him as a foolish Muslim when he converts to Islam. He is indoctrinated with radical Islamic tenets without knowing the true Islamic teachings deeply and holistically as contained in the following quotation.

One evening, he asks Hamid why he has not been sent to Afghanistan to fight: "I can't stay here doing nothing! Have you seen how they treat our people? Have you heard the lies they tell us? They act like we're rats, Hamid! I want to serve Allah with all my strength." (p.294).

This quote becomes a situational irony because François wants to 'serve God' but by fighting through terror which ironically he himself does not know and realize that what he is doing is a terror and not in accordance with Islam teachings. A very high spirit for jihad without any complete understanding creates François as a naïve, easily fooled and exploited character.

In the radical militant group he participates in, François has always been indoctrinated with a radical notion so that he strongly intends to go to Afghanistan. After going through such a military exercise and through a long process, he finally gets a chance to fight for jihad in Afghanistan. However, through the narrator's narration, it is depicted that what he experiences in ' $\mathrm{jihad}$ ' movement reversed the assumption that he is a brave man. When he arrives in Yemen, he is caught and interrogated about his identity. However, when he is being interrogated, he feels so scared that he urinates and weeps. 


\begin{abstract}
"Remember anything now? Is it coming back to you? I'll ask you again: Why did you come to Yemen? You're an Islamist, aren't you?" No, no. Djamal trembles and pisses himself: he feels the warm liquid run down his legs and feels ashamed. ... He starts crying and they call him a woman, lock him up in a tiny, dark cell with three other bearded men, all dull-eyed and shaggy-haired.(p.296-297)
\end{abstract}

This depiction creates an impression that François is actually a coward and a loser man even though he has passed various physical and mental exercises. This cowardly character is further strengthened by an event when he is arrested in Afghanistan. In fear, François tries to change his identity. He says that he is not a jihadist, he knows nothing and he is just an ordinary Frenchman (p. 306). This situation is a kind of dramatical irony since François as a character does not realize that he is only utilized by the militant group, while the readers know what is happening to him.

Karine Tuil, through the characterization of François, is as if trying to show that Islamic followers are fatalists who only accept any doctrine without thinking with common sense. In this regard, the narrator also recounts that "In the nights that follow Hamid's revelation, Djamal sleeps badly. He dreams that he is too is going away, carrying a gun, a hero" (p.301).

With situational irony, this narration seems to make fun of the Muslims who struggles with their innocence and considers themselves a hero. In fact, François does not know what he is really doing. He is trapped in the desire to reach heaven but does the wrong way.

By giving negative characterization to all Muslims characters in the novel, Tuil does not provide even a tiny space of a good image for Muslims in this novel. She seems to convey the message of Islam as a barbarous religion through a narration containing a paradox. In a part of the story it is illustrated how François and his group read the Quran, but what Tuil (through the narrator) 'cites' is a sentence which is regarded as a part of Quran verses without any complete context, which is written as follow, "and our enemies shall perish beneath our sword, we shall invade their lands, we shall kill them all unto the last!" (p.306). This narration seems to indicate that Islam teaches barbarism by inviting its followers to kill their enemies into the last.

Tuil even names the characters who recruit foreigners to fight in jihad with Arabic names such as 'Mohammed' and 'Abdel of Mecca' (p.305). This naming gives the image as if the Arabic name is characterized by acts of terrorism and radicalism. This suggests that Tuil has a tendency to say that terrorist actors have Arabic names like 'Muhammad' (which is actually the name of a glorified prophet and apostle in Islam). She also attaches the name 'Mecca' behind the name 'Abdel', which is very visible that 'Mecca', as a symbol of the holy place for Muslims, is then attached to the name of a terrorist. This depiction is a very tendentious situational irony. Anxiety and fear over terrorism have gradually become a part of Muslims' identity (Elver, 2012: 136).

After all discussion in this part, it can be seen that on one side Tuil seems to try to criticize the naïve Muslims who shallowly understand Islam. They just make Islam as their simply identity instead of their complete identity (body, mind, and soul). They only take it for granted whatever indoctrinated to them without any critical thought, especially about the issue of Jihad. However, on the other side, she makes fun of Muslims characters whom she gives them all negative traits, and she also carelessly cites a sentence which is regarded as the part of verses in Quran. This action gives impact on certain negative framing about Islam, and this makes her Islamophobic. The framing is culturally racist by describing Muslims as 'uncivilized', 'barbaric', 'primitive', 'underdeveloped', 'authoritarian', and 'terrorist' (Grosfoguel, 2012: 13). Islam through the characters is then seen as a religion of violence, aggressive, threatening, and supportive of terrorism.

\section{SENTIMENT ON HIJAB ISSUE}

In February 2004 French government decided to ban the head scarf from schools and bar access to education to anyone wearing a religious insignia. The combination of these measures locates Muslim women as sometimes-unwilling emblems of combative Islam in the cross fire between 
faith and state policies (Afshar, 2006:122). The choice to wear the hijab is a political act to define Muslim women as 'different' and as Muslims at a time when rampant Islamophobia makes them vulnerable to attack and harassment for this act of defiance (Afshar, 2006:140).

Karine Tuil in other respects also hides her anti-Islam idea through the narration and through the characters' behavior related to hijab issue. In some of the narration in the novel, there seems to be a tendency to question the allegiance of Islamic tenets which ask the women to wear hijab, as seen in the events when Francois arrived in Islamabad. The narrator (author) describes the setting atmosphere with the following sentence "The mountains vanish into the distance. Women imprisoned in chadors carry children with sunweathered faces." (p. 303).

The phrase 'imprisoned in chadors' implies that the chador/veil is a jail for women. The word 'prison' implies a place that confines, limits motion and freedom. The chador/veil as a Muslim women (Muslima) clothing in this narration is defined as a form of confinement of women's freedom by religious teachings.

Tuil probably assumes that Islam has imprisoned the women with hijab, forcing them to wear it and make them suffer. Muslim women seem to have no choice with the indoctrination of hijab. Straw (in Allen, 2010: 95) strengthens Tuil's view with his assertion that Muslim women who wear the niqab could make relations between communities more difficult. Hijab disseminated meanings about Muslim women as inferior, oppressed and of being second class citizens (Allen, 2010: 166).

This idea becomes a situational irony as hijab in Islam is actually worn to maintain the honor and glory of a woman. Hijab frees women from fashion capitalist hegemony and frees them to determine their own glory, not to imprison them. This irony then shows how Tuil is making a negative frame on hijab. She tends to be eurocentric, which considers Islam as an irrational religion. The adherents become fatalists as they are indoctrinated by the Islamic teachings (Grosfoguel, 2012:25). In this case, the adherents are seen as being a 'victim' of a religion.

\section{SENTIMENTS ON MALE DOMINATION ISSUE}

This sentiment is also shown when François has been renamed Djamal and has been getting much indoctrination from militant groups. The narrator tells how his mother is very scared and how François imposes his mother's rules.

His mother is terrified by this desire for purity, this moral intransigence, this war like rigor, but she says nothing and bows down to the new rules issued by her son: you will wear a veil at home and outside...you will not speak to men...you will not contradict me. And that's how it is, how it should be: the docile woman, executing his orders, and him, the omnipotent monarch who rules/ controls/forbids (p.293).

François forces his mother to wear hijab both inside and outside the house. The command regarding the imposition of hijab conveyed by François as a man through the narrator of the narrator gives the impression that hijab is a coercive rule, given through male domination of woman, as a forced obligation, not as a one's consciousness. This is reinforced by an event when François (Djamal) once invites Hamid to his apartment and he commands his mother to wear hijab. Nawel refuses but ultimately gives up under pressure (p. 290). Diction 'under pressure' in the narration confirms that Muslim women wearing hijab because of the coercion and pressure of men who control them.

Another command given by François to his mother is that she should not speak to men and should not argue with François (as a man). This further emphasizes how Tuil brings a message of religious sentiment to the readers. She gives an idea of how an 'obedient' Muslim man treats a woman. She is forbidden to socialize with the opposite sex and should not oppose the will of men. Women, in this case, seem to be male prisoners, who have no ability to be independent and have their own choices. This event sharpened the sentimental idea of women in Islam, that is how exactly a woman should be, i.e. keeping the commandments of men, and it is the men who have the most powerful to lead, control, ask and forbid. 
Tuil also shows anti-Muslim sentiment by showing how a woman seems to be traded through marriage and she has no will of herself. This appears in an event when François (Djamal) has divorced from Nora and he is looking for a new wife. In Morocco, he meets his future wife, an innocent 16-year-old girl, whom the narrator tells in a footnote, named Latifa Oualil, a girl who does not know what she wants in life. The narrator tells the situation when Francois (Djamal) is marrying Latifa. It is said that "He has a discussion with the father, where they negotiate the dowry sum, then married the girl a few days later." (p. 301).

The 'negotiate' diction here implies the meaning of 'bargaining', and it gives the impression of how a Muslim woman is treated like a commodity that can be bargained, or even like a slave that is bought from her master. This situation gives a bad impression of how a very young Muslim girl, who is very innocent and naïve then 'be bought' from her parents to fulfill a man's desire.

Still related to the sentiments of Islamic teachings related to women, Tuil seems to make a mockery of the heavenly nymphs. When militant jihad forces are in Afghanistan, the narrator tells about their life dream that appears in their dream as they sleep.

They sleep on the ground... and dream of wome $\mathrm{n}$ whose marble-like bodies they unco $\mathrm{v}$ er beneath the thickest chadors, pure virgins who do not cry out during lovemaking, who offer themselves without resi stance open and close their thighs upon command, oh, it's so good, they thin $\mathrm{k}$, like the celestial paradise, those hairless, unblemished bodies waiting to be defl owered (p.306).

The above narration contains a mockery that heavenly angels are holy women who will not scream during intercourse, who will voluntarily offer themselves to have sex and will open and close their thighs when asked. The emphasis given by the narrator, in this case, is only about the crotch. This narration also contains a mockery of the militant forces, that they will do anything for th is crotch affair.
This narration contains a very strong situational irony by making fun of situations that differ greatly from the underlying reality of Islamic teachings. This irony tends to be made to insult Muslims in general to play the function of irony as aggression. It is often assumed that irony is an especially nasty form of criticism, more insulting than a directly negative statement. Irony has been described as a way of mocking and thereby humiliating the "victim" of the irony (Dews, Shelly et al. in Gibson and Herbert, 2002:299).

In this part of discussion, it can be seen, again, that on one side Tuil seems to try to criticize the naïve Muslims who shallowly embracing Islam. It is a shallow understanding that makes Muslims act naively, such as treating women badly (such as a commodity). However, on the other side, Tuil makes this issue becomes a mockery material of Islam. She also makes fun of Islamic tenets which are basically believed by Muslims, such as the nymphs in heaven, as have been discussed above. This thing gives impact on certain negative framing about Islam, that Islam is irrational by mentioning 'unreal' heavenly nymphs and asks its followers to pursue the dream irrationally. This is a kind of situational irony, in which the issue is different with the pure Islamic tenets.

The ironies in the story then show how Tuil is an Islamophobic with orientalist views. She frames Islam as an uncivilized religion with gender prejudices, creating male dominance and discriminating against women. Women are oppressed at the hands of man (Grosfoguel, 2012:16). Women are only used as objects of desire satisfaction and lust of men. They are not free of themselves.

From this case we can see that it is not through the stereotyping of physical characteristics that Islamophobia spreads, but through the misrepresentation of the Muslim world, and the representation of their life-style as alien from Western society. The misuse of Islamic texts, the reproduction of orientalist, and colonialist images of Muslim men as violent and patriarchal and of Muslim women as submissive and oppressed, facilitate the representation of Islam as barbaric culture, and hence founded on anti-Western values (Maranci, 2004:107). 


\section{SENTIMENT ON ANTI-SEMITISM VS ANTI- ISLAM ISSUE}

After 9/11 attack, Islam is intensely considered demonic. The demonic aspects of Islamism, ac cording to Kalmar (2009: 141), "are the despotism and fanatical obedience to a strict God and the uncompromising legal code. The murderous hostility to western civilization plays back the demonic aspects of the classic construction of the Semite. Anti-Islamism is the new anti-Semitism." So, Islamophobia is regarded as the new AntiSemitism as Muslim obey the 'strict' rules of God which might lead to demonic action.

In her attitude towards Islam, Tuil in some of the narration shows how Islamophobia occurs in Europe, especially in France and America (as a setting of TAoR). Through Hamid's character, Tuil describes how France treats Arabs or Muslims as follows.

.. but France is a racist country. They deliberately serve pork in school cafeterias so our children will go hungry, because they want to provoke us... I am certain to be stopped almost every time I drive my car, and if I take the Metro, I am always one of the people whose papers they check. As an Arab, you have no chance of finding a job- and as for a nice place to live, forget it. The French invited our parents here by promising them Utopia, and instead they he rded them like beasts into dormitory towns and exploited them, mistreated them. And now they want to get rid of them and they expect us, their children to say thank yo u? (p.290-291).

France is characterized by a permanent paradox. It is a European country where Islam is officially institutionalized but it also exists within a Western society where Islamophobic tendencies are the strongest and most recurrent (Gessier, 2010:45). The anti-Muslim is reflected through discrimination in key areas for integration such as employment, education and housing (Munoz, 2010: 23, Taras, 2012:428). This condition makes Samir Tahar changes his identity. He feels that antiIslamic sentiment has made him difficult to find work. However, interestingly, in TAoR Tuil seeks to juxtapose anti-Islam issues with anti-Semitism or anti-Jewish.

She brings up a Jewish, Pierre Levi, to express her views on this subject in an event when Samir Tahar narrates his true identity and reveals the reason why he changes his identity to Jew, that is because of anti-Muslim sentiments in France.

"Oh, I've had my share of humiliations as a Jew, believe me. Segregation, exclusion... I've experienced those things. You think I wasn't called a "filthy Jew" in school? You think I never got dumped by a girl because she discovers I was Jewish? You think I never heard the worst Anti-Semitism clichés from people I considered my closest friends? Oh, and I think I've lost opportunities because of my name too. We've all been there..." (p.225).

In this narration Tuil as if tries to convey an idea that not only Islam, Jews also feel how they are discriminated against by those who hate them. Anti-Jewish also became a serious issue in French (Silverstein, 2008:20-21). They also feel how they are bitterly racistly treated just because they are Jewish. However, Said (1977:286) recognized that the Jews seem to free themselves of the burden of Semitism and anti-Semitism in the late 1970s. The Arabs and Muslims remain as the only Semites, demonized in much the same ways that the Jews had been before.

Tuil, through the narrator, comments on 'the most persecuted competition' among Muslims and Jews in Pierre Lévy's speech as his dialogue with Samir Tahar.

The truth is that Arabs feel humiliated and Jews feel persecuted. The truth is that Arabs still react as if they are being colonized, oppressed, and the Jews as if they are still at risk of being exterminated. Each group has to come to terms with that, and sometimes that leads to a kind of competitive victims; who has suffered the most? Who is suffering the most? Who's got the highest death toll? Who's the oppressor and who's the victim? We are! No, we are! It's pitiful, pathetic. It depresses me. It depresses me to exist only through this prism of martyrdom, this 
contest where the weakest are the winners. (p.225)

In this dialogue, Tuil seems to express her disagreement with the people who argue about who are the worst victims of anti-Semitism and antiIslam, and those who are the most debilitated are the winners. However, behind Tuil's view of this racism, she apparently 'wins' the Jews. None of the Jewish figures are badly portrayed in TAoR. Pierre Lévy and the Berg family (Rahm and Ruth Berg) as important characters in this story are described as successful, wealthy, famous and influential people. Pierre Lévy (the Jew) is presented to advise Samir (Muslim) not to be a loser on the issue of racism and how to survive in such conditions. In this case, it seems that Tuil advises Muslims to learn from Jews who have successfully passed Anti-Semitism issues by winning and mastering various aspects of life.

In the end, when Samir (a Muslim) is jailed for allegedly financing terrorism acts committed by François (Djamal), it is Pierre Lévy (a Jew) who frees him from the charges and the prison. If the pattern is made, the Jewish and Muslim characters in TAoR (compared between Pierre Lévy and Samir Tahar/ François Yahyaoui) can be read as follows:

- Jews (Pierre Lévy): success and wealthy, gains the wealth from genuine identity as Jew, a survivor of Anti-Semitism, Muslim 'savior', and no narrations about his sexual life.

- Muslim (Samir Tahar): success and wealthy, gains the wealth from fake identity as a Jew, a loser, cannot survive from anti-Islam, and sex maniac.

- Muslim (François Yahyaoui): poor, loser, fool, naïve, coward, and sex maniac.

This pattern further emphasizes how Karine Tuil considers that Anti-Semitism and AntiIslam (Islamophobia) are the same matters, but Muslims are weak and cannot get out of this problem. She only makes fun of Islam and Muslims as the religion of the losers. Karine Tuil thus has injected her ideology hidden in every narration, dialogue and the traits of the characters in her novel. She highlights the consequences of Islamophobia in France by making the Muslim characters act as losers.

\section{CONCLUSION}

Islamophobia is an act and concept that leads to hatred against Islam and Muslims. Islamophobia is not only done through violent acts against Muslims, but it is also done through idea, paradigm or ideology hidden in written media such as articles in the newspaper, online articles, or even through fictional media such as novels.

Karine Tuil's The Age of Reinvention (TAoR) novel contains full of Islamophobic issues conveyed through the narrations, dialogues, and characterization of its Muslim characters. She also shows he negative sentiments towards Islam and Muslims emerged through the through the issues of hijab, gender prejudice and Anti-Semitism versus anti-Islam.

Through dramatical and situational ironies, the author injects an Islamophobic ideology. Through characterizations containing situational irony, Muslims are portrayed as uncivilized, losers, liars, sex maniac, backward, authoritarian and terrorist. These negative sentiments show that the author has an ideology of cultural racism.

The other ideology found in the analysis is the eurocentric view that describes Islam as an irrational religion, indoctrinating its adherents with 'unreasonable' teachings such as an obligation for the women to wear hijab. Tuil also mocks Islamic teachings that promise heavenly and beautiful nymphs for Islamic Jihad-fighters. Through the narration, she assumes that Muslims are fatalists, irrational and become the 'victims' of the doctrine of false religious teachings.

In addition, she also becomes an orientalist by assuming that Islam is a religion with gender prejudices, in which men are dominant and powerful over women, and women are discriminated by the duty to fully obey the men. Tuil's views through narrations and dialogues in TAoR make this novel Islamophobic. 


\section{REFERENCES}

Afshar, Haleh, Myfanwy Franks and Rob Aitken (2006). Feminism, Islampohobia and Identities. Gender Studies (05), $1 \leq \wedge 119$. Retrieved from http://journals.sagepub.com/doi/abs/10.1111/ j.1467-9248.2005.00528.x

Allen, Christoper (2010). Islamophobia. UK: Ashgate.

Attardo, Salvatore (2000). Irony as Relevant Inappropriateness. Journal of Pragmatics 32, 93-826. Retrieved from omero.humnet.unipi. it/matdid/372/Attardo_Irony.pdf

Bayrakli, Enes and Farid Hafez (Eds) (2015). European Islamophobia Report. Retrieved from $w w w$. islamophobiaeurope.com/reports/2015/en/ EIR_2015.pdf

Colebrook, Claire (2004). Irony: the New Critical Idiom. London, England: Routledge.

Dews, Shelly et al. (2002). Why Not Say It Directly? The Social Functions of Irony. Discourse Processes, 19 (3), 347-367. DOI: 10.1080/01638539509544922.

Garner, Steve and Saher Selod (2014). The Racialization of Muslims: Empirical Studies of Islamophobia. Critical Sociology, 1-11. DOI: $10.1177 / 0896920514531606$.

Gessier, Vincent (2010). Islamophobia: a French Specificity in Europe? Human Architecture: Jurnal of the Sociology of Self-Knowledge, 8 (2), 39-46. Retrieved from http://scholarworks. umb.edu/humanarchitecture/vol8/iss2/6/

Grosfoguel, Ramon (2012). The Multiple Faces of Islamophobia. Islamophobia Studies Journal, 1(1), 10-32. Retrieved from https://www.okcir. com/ISJ-FALL2012-Vol1-No1-CRG.pdf.

Elver, Hilal (2012). Racializing Islam Before and After 9/11: From Melting Pot to Islamophobia. A Journal of the University of Iowa College of Law, 21, 119-174. Retrieved from http://www. academia.edu/11934102/Racialization of Islam_before

_and_after_9_11_From_melting_pot_to_Islamophobia

Iqbal, Zafar (2010). Understanding Islamophobia: Conceptualizing and Measuring the Construct. European Journal of Social Sciences, 13 (4), 574-590. Retrieved from http://www. mediadiscourse.pk/media/Islamophobia published_paper.pdf

Joseph, Suad and Benjamin D'harlingue (2012). The Wall Street Journal's Muslims: Representing Islam in American Print News Media.
IslamophobiaStudiesJournal,1(1),133-164.

Kabgani, Sajjad (2013). Representation of Muslim Women in Non-Islamic Media; A Critical Discourse Analysis Study in Guardian. International Journal of Women's Research, 3 (1), 57-78.DOI: 10.22059/ijwr.2013.30590.

Kalmar, Ivan Davidson (2009). Anti-Semitism and Islamophobia: The Formation of a Secret. Human Architecture: Journal of the Sociology of Self-Knowledge, 7 (2), 135144. Retrieved from https://tspace.library. utoronto.ca/bitstream/1807/.../1/ antisemitism. islamophobia.pdf

Kunst, Jonas R, et al. (2012). Coping with Islamophobia: The effects of Religious Stigma on Muslim Minorities 'Identity Formation. International Journal of Intercultural Relations, 36, 518532. Retrieved from http://www.academia. edu/2222313/Coping_with_Islamo

phobia_The_effects_of_religious_stigma_on_Muslim _ minorities_identity_formation

López, Fernando Bravo (2011). Towards a Definition of Islamophobia: Approximations of the Early Twentieth Century. Ethnic and Racial Studies, 34 (4), 556-573. DOI: $10.1080 / 01419870.2010 .528440$.

Manqoush, Riyad Abdurahman, Yusof and Hashim (2014). Islamophobic Irony in American Fiction: A Critical Analysis of Lorraine Adams' Harbor and John Updike's Terrorist. American International Journal of Contemporary Research, 4 (3), 73-80.

Maranci, Gabriele (2004). Multiculturalism, Islam and the Clash of Civilizations Theory: Rethinking Islamophobia. Culture and Religion, 5 (1), 105-117. Retrieved from www.marranci.net/ official..._Marranci_Culture_and_Religion_ Multiculturalism.pdf

Muñoz, Gema Martín (2010). Unconscious Islamophobia. Human Architecture: Jurnal of the Sociology of Self-Knowledge, 8 (2), 2128. Retrieved from http://scholarworks.umb. edu/humanarchitecture/vol8/iss2/4/

Ramberg, Ingrid (2004). Islamophobia and its consequences on Young People. Seminar report. Hungary: European Youth Centre Budapest.

Said, Edward (1977). Orientalism. London: Penguin.

Sayyid, S (2011). Racism and Islamophobia. MnM Commentary, (4), 1-4. Retrieved from https:// 
www.unisa.edu.au/Documents/EASS/MnM/ commentaries/sayyid-racism-islamophobia. pdf

Sayyid, S. A Measure of Islamophobia. (2014). IslamophobiaStudiesJournalVolume,2(1),

10-25. Retrieved from

http://eprints.whiterose.ac.uk/83697/1/Sayyid $\% 20$ A $\% 20$ Measure $\% 20$ of $\% 20$ Islamophobia- $\% 20$ journal\%20version.pdf
Silverstein, Paul A. (2008). The context of Antisemitism and Islamophobia in France. Patterns of Prejudice, 42(1), 1-26. DOI: $10.1080 / 00313220701805877$.

Taras, Raymond (2013). Islamophobia never stands still': race, religion, and culture. Ethnic and Racial Studies, 36 (3), 417-433. DOI: 10.1080/01419870.2013.734388.

Tuil, Karine (2015). The Age of Reinvention. New York: Atria Books. 